\title{
Grundtvigs bidrag til udvikling af danske nationale symboler
}

\author{
Af Inge Adriansen
}

Grundtvig har nok været den mest betydningsfulde producent af historisk bevidsthed i Danmark, således har historikeren Jens Chr. Manniche karakteriseret ham (Manniche 1992, 255). Og Grundtvig har fortsat betydning for vore forestillinger om danskhed, men det er et problem, at det kun er en lille del af det enorme forfatterskab og den komplekse idéverden, som vi sædvanligvis præsenteres for. Grundtvig var i perioder af sit liv, hvad mange i dag vil opfatte som nationalist. Men det bør understreges, at han altid fremhævede, at danskheden har sin historiske og sin geografiske begrænsning. Desværre er der i nationalsymbolikken kun meget ringe plads til denne kompleksitet, og Grundtvigs billedsprog er så dunkelt og stritter i så mange retninger, at det ikke har været egnet til direkte at omsættes til let aflæselige symboler (Toldberg 1950).

Alligevel har dette billedsprog haft en afgørende betydning for udviklingen af den nationale symbolik, fordi Grundtvig var hovedkraften bag skabelsen af den særlige sammenfletning af kristen, national og social identitet, som mange danske oplever som ikke blot selvfølgelig, men også naturgroet, noget der har været her fra tidernes morgen. Denne virkningshistorie illustrerer smukt Grundtvigs tanker om ordet, der skaber, hvad det nævner.

Nationale symboler rummer forestillingen om et reelt fællesskab i befolkningen, uafhængigt af alle økonomiske, sociale og kulturelle forskelle. Fællesskabet fremstår ikke blot som synkront ved at favne alle medborgere, men også som diakront ved at række langt tilbage i tiden og således omfatte talrige slægtled. Forestillingen om denne særlige samhørighed er med til at legitimere staten som en suveræn enhed, og derfor er der i alle stater - som ikke udelukkende hviler på en religiøs begrundelse - blevet skabt symboler, der bruges udadtil ved at vise uafhængighed $\mathrm{i}$ forhold til omverdenen og indadtil ved at fremstå som billeder på fællesskabet mellem borgerne og deres opslutning bag styret. De nationale symboler har således en dobbelt funktion: De tjener til at afgrænse en stat i forhold til andre stater og kan undertiden også afgrænse en nation (i betydningen et folk) $\mathrm{i}$ forhold til nationale minoriteter inden for statens grænser.

Selvom der anvendes nationale symboler i alle stater, opfattes de i reglen som udtryk for noget helt særegent for den pågældende nation, så at sige udsprunget af folkets dyb. Dette gælder også for mange danskeres fortolkninger af den nationale symbolik, ikke mindst fædrelandssangene og flagskikken. De nationale symboler er med til at 
skabe samhørighed og give sammenhængskraft, og herved medvirker de til at gøre undersåtter til et folk. Kort sagt - den nationale symbolik fungerer som en form for mentalt kit. ${ }^{1}$

\section{Den officielle symbolik og Grundtvig}

Der findes en række statslige symboler og kendetegn, der kendetegner statsmagten over for borgerne og anvendes ved offentlige ceremonier såvel i ind- som udland, for eksempel ved regentens eller ministres officielle besøg i udlandet og ved modtagelsen af medlemmer af fremmede regeringer. De statslige symboler bliver således anvendt både indadtil og udadtil, og de bliver tillige brugt $\mathrm{i}$ mere folkelige sammenhænge, blandt andet ved nationale festdage og vigtige sportsbegivenheder.

Den officielle danske symbolik består af seks hovedelementer, hvoraf de tre øverste især er forbeholdt statsmagten. Det drejer sig om rigsvåben, regent og forfatning, $\mathrm{og} \mathrm{de}$ er grundigt beskrevet $\mathrm{i}$ bekendtgørelser og love, så der ikke hersker megen tvivl om deres funktioner, fortolkninger og den tilladte brug. Om brugen af de tre andre officielle symboler, nationalflag, nationalsang og nationaldag, er der i tidens løb udviklet et regelsæt, der i vid udstrækning er uskrevet. Det er i øvrigt symboler, der ikke udelukkende må anvendes af statsmagten, men også må bruges af befolkningen, og det sker i vidt omfang i alle sociale lag.

Grundtvig har kun haft ret begrænset betydning for udviklingen af den officielle symbolik. Som bekendt var Grundtvig tilhænger af enevælden og bestemt ikke nogen fortaler for fri forfatning. Hans forestilling om det ideelle styre afspejler sig i fyndordet "KongeHaand og Folke-Stemme, / Lige stærke, lige fri", og i møderne i Danske Samfund var forfatningsspørgsmålet noget, der gang på gang udløste heftig debat.

I Et Blad af Jyllands Rimkrønike skriver han om forbindelsen mellem Danmarkshistorien og Bibelen. Løverne i det danske rigsvåben fremstår her ikke blot som spejlinger af den himmelske Judaløve, men også som efterkommere af den løve, der skulle have været på Amleths skjold. Det er Danmarkshistorie fra den hedenske tid, som her bindes sammen med Bibelens fortællinger (Auken 2005, 286 f.). Men dette billedsprog fik ikke nogen virkningshistorie i samtiden.

Grundtvig har flere gange skrevet om Dannebrog, blandt andet ved Christian VIII's fødselsdag i 1842, hvor han hyldede regenten for at have indført Dannebrog, det gamle orlogsflag, som fælles flag for hele den danske hær. ${ }^{2}$ Det gamle rigsbanner fra Valdemar Sejrs dage kom nu tilbage på land efter århundreders sejrrige togt på havene, og Christian VIII's initiativ med hensyn til at skabe et fælles symbol for alle hærafdelinger tolkes som et udtryk for kongens danskhed: 
Hvilket Varsel kunde nu vel nævnes, der skulde vække gladere Forventninger hos Dannemænd end den saa tit seierrige, altid hæderkrandsede Dannebrogs Landgang, til ligesom at boe og bygge hos os, til at svæve over Marken, som over Havet, til at svæve os for Øine under al vor Idræt, som den svævede for Christian den Fjerde, for Jul og Tordenskjold og Villemoes, og for de Tusinder fra Slægt til Slægt, hvis Navne vi ei kan opregne, men hvis Ære grønnes med Skoven, hvis Minde kun uddøer med Danmarks Hjerte! Er det vel Tant og tomme Ord, at det Danske Flag, med Æren bekendt "fra Chinas Kyst til Østersøens Grændse" ved paany at blive hele Rigets, hele Folkets Konge-Banner, varsler høit for Danskhedens Seier i sin Kreds, i vort Hjem, i alle Dannemænds Fæderneland; eller er det ikke soleklart, at Danskhed throner i den Konges Barm, der saaledes grundfæster og udbreder vort gamle Folke-Banner (Lundgreen-Nielsen 1992, 61).

Grundtvigs skildring af Dannebrog, der "paany" blev hele folkets flag, blev fremført mundtligt ved et foredrag i Danske Samfund og blev ikke trykt i samtiden ${ }^{3}$, men den viser, hvorledes han havde fingeren på den folkelige puls. Ganske vist var forestillingen om det gamle "FolkeBanner" ikke rigtig, men det var en udbredt opfattelse, og den må formodes at have fremmet den folkelige flagskik, der var under hastig udvikling. Brugen af Dannebrog var forbeholdt statsmagten helt frem til 1854, og så sent som i 1834 havde Frederik VI understreget forbuddet mod enhver form for folkelig flagning, men uden større virkning. I stigende grad begyndte dele af befolkningen at benytte statens og kongemagtens symbol som deres eget festtegn. Da Grundtvig i 1844 var en af hovedtalerne ved folkefesten på Skamlingsbanken 4. juli, vajede der talrige dannebrogsflag på banken, og det var både splitflag og stutflag, som det fremgår af et træsnit fra festpladsen.

Grundtvig skrev flere sange om Dannebrog, dels i 1837 "Hil dig, vor Fane", der er en gendigtning af en latinsk hymne "Salve crux arbor", dels under 1864-krigen, hvor han genbrugte de to første vers heraf og tilføjede tre mere, der skulle være en trøst i den aktuelle trussel mod danskheden. J. P. E. Hartmann skrev en melodi hertil, og digtet indgik i P. Rørdams udgivelse Psalmer for Danske Krigere, som udkom i forsommeren 1864, mens krigen endnu var i gang. De første tre vers gengives her:

Hil dig, vor Fane!

Kors-Banner hvidt!

Holde paa Bane

Med dig vi Skridt;

Vis er os Krandsen

Gyldenaars-Glandsen.

Danskerne følge dig frit!

Fjenderne grue,

Meer end for Sværd, 
Ved dig at skue,

Plantet dem nær;

Hvor du dig hæver,

Seier omsvæver

Kors-Herrens signede Hær!

Kærlig omfavned

Dig Dannemænd,

Dannebrogs-Navnet

Bære du end;

Himlen til Ære

Altid du bære

Navnet med Seier igen!

(Rørdam 1864, 62).

Salmens højtstemte tone lå uendeligt fjernt fra krigens realiteter. Dannebrog blev ikke ført i spidsen for den sejrende hær - tværtimod! Den danske overkommando havde forudset nederlaget på Dybbøl og ønskede at forhindre, at regimentsfanerne faldt i fjendens hænder. Derfor skulle fanerne afleveres et centralt sted bag fronten, før de enkelte hærafdelinger drog ud i forreste linje (Adriansen 1999, 44). Salmen fremstår herved som et forsøg på besværgelse af virkeligheden, og den har næppe vundet større udbredelse blandt de indkaldte soldater. Det har i hvert fald ikke været muligt at finde den i håndskrevne sanghefter fra felten eller som skillingstryk.

Der er som bekendt to danske nationalsange, Johannes Ewalds "Kong Christian stod ved højen Mast" og Adam Oehlenschlägers "Der er et yndigt Land". Med jævne mellemrum debatteres nationalsangene, og talrige andre sange er blevet foreslået som afløsning, og blandt disse fremhæves ofte en af Grundtvigs sange, "Langt høiere Bjerge saa vide paa Jord". Den ville være et helt indlysende valg, da den kan tolkes som et udtryk for den ydmyge selvhævdelse, som blev en vigtig del af dansk selvforståelse afståelsen først af Norge i 1814 og derpå af hertugdømmerne i 1864. Andre tolkninger af sangen er dog også mulige (Lundgreen-Nielsen 1982, 289-307). Tiden til et nationalsangsskifte er imidlertid fuldstændig forpasset. Fra sidste halvdel af 1980 'erne har "Der er et yndigt land" vundet en klar forrang, fordi den bruges i forbindelse med landskampe, og ikke mindst fodboldentusiaster kan uden besvær skråle de fire strofer af Oehlenschlägers sang, som gengives i nutidens sangbøger.

Grundtvig har heller ikke fået nogen betydning for valget af nationaldage. Her gjorde han ellers en ihærdig anstrengelse med at pege på hele tre dage, som burde være verdslige mindedage. Det skete i 1840'erne, efter at han havde erkendt, at hans forsøg på at få den nordiske mytologi indført som et hovedemne i foreningen Danske Samfund var slået fejl. I stedet for den gamle mytologi ville Grundtvig nu skabe en ny dansk idéverden (Lundgreen-Nielsen 1992, 68). 


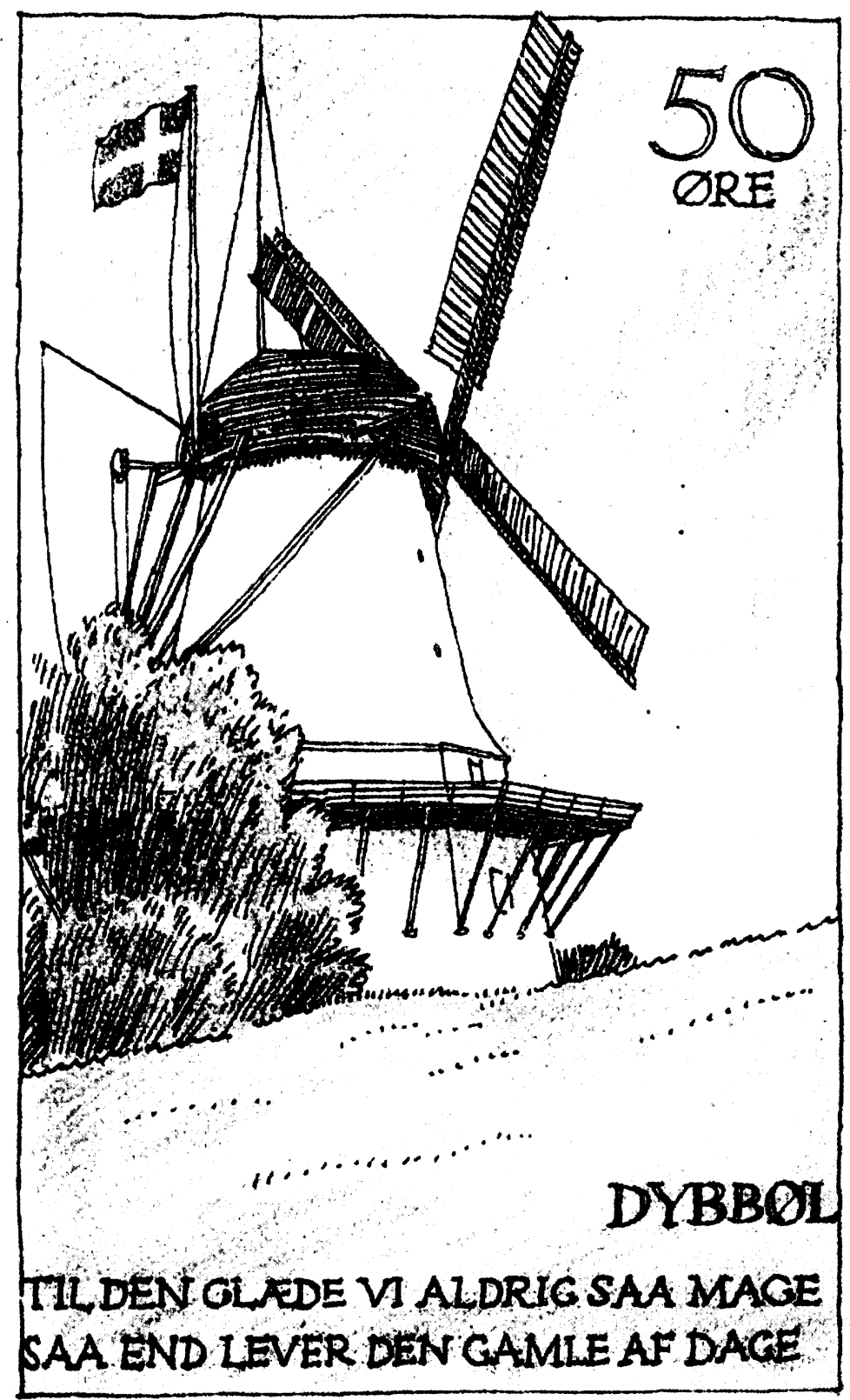

Nødpengeseddel fra Dybbøl foråret 1920 med citat af Grundtvig. Efter Første Verdenskrig var der stor mangel på skillemønt i Slesvig, og for at bøde herpå udstedte mange kommuner egne pengesedler. I Dybbøl kommune blev 50-øre-sedlen prydet med Dybbøl Mølle med et vajende dannebrog og et citat fra "Fæderneland ved den bølgende Strand". Denne sammenkobling af det nationale og kristne var meget udbredt $i$ tiden omkring 1920. (Foto: Museum Sønderjylland - Sønderborg Slot.) 
Et virksomt middel skulle være afholdelsen af nationale mindedage. Hidtil havde man kun haft kongens og dronningens fødselsdage som fælles fest- og mindedage. Men nu foreslog Grundtvig tre datoer for historiske begivenheder: Den 11. februar - svenskernes storm på København i 1659, den 2. april - slaget på Reden og den 28. maj indførelsen af de rådgivende stænderforsamlinger, der jo var et udtryk for tanken om "Konge-Haand og Folke-Stemme". Det eneste af forslagene, der slog an, var 28. maj, og det var ikke Grundtvigs fortjeneste, for denne dato var blevet markeret allerede fra 1832, året efter kundgørelsen om stænderforsamlingen, og fejringen af 28. maj vakte i øvrigt kongemagtens misbilligelse. Det kan synes forbavsende, at han pegede på to mindedage for militære begivenheder $\mathrm{i}$ hovedstaden og ikke på 15. juni, dagen for Dannebrogs himmelfald, eller 20. juni, datoen for stavnsbåndets løsen.

Hvis man betragter de seks officielle symboler under et, ser det ud til, at Grundtvig ikke har haft nogen særlig betydning for udviklingen af denne billedverden, selvom han har skrevet om og refereret til dem, derimod er Grundtvigs betydning klart større for udviklingen af en uofficiel symbolik.

\section{De uofficielle symbolers brogede verden}

Uofficielle symboler har spillet en væsentlig rolle for skabelse, opretholdelse og udbygning af forestillinger om danskhed siden de første årtier af 1800-tallet. De kan tolkes som billedlige udtryk for erindringsfællesskaber med fortidsforståelse som det centrale omdrejningspunkt. Brugen af uofficielle nationale symboler er gradvist vokset frem, og den er underlagt stadige forandringsprocesser. Den uofficielle symbolik er ikke underlagt nogen bestemmelser fra lovmagtens side. Den varierer både over tid og rum og er i højere grad end den officielle knyttet til historien og til nationens specifikke udvikling, men der er tre felter, som kan betegnes som kulturelle kerneområder - det er sproget, historien og kulturlandskabet - og der er en stor europæisk enighed om, at disse tre områder er centrale for den kulturelle identitet. De indgår i de europæiske nationale bevægelsers "grammatik", og hver nation har sine særlige bøjningsmønstre inden for denne grammatik. De enkelte elementer i den uofficielle symbolik kan variere meget fra nation til nation, og de bestemmes især af landets historie, natur og geografi. I Danmark er bøgeskoven således blevet til en del af den nationale natur, hvorimod det i Tyskland er nåleskoven med den tætte masse af høje ranke træer, der indgår i det nationale landskabsbillede. 


\section{Mytologien}

Grundtvigs første selvstændige udgivelse var Maskeradeballet $i$ Dannemark 1808. Et Syn, der blev skrevet som reaktion på Københavns bombardement i 1807 og befolkningens tilsyneladende sorgløshed. Grundtvig havde opholdt sig på Langeland under hovedstadens ødelæggelse og således ikke oplevet krigen på førstehånd, men han led med sit land $\mathrm{og}$ anråbte Gud om frelse for det. Den nordiske mytologi og kristendommen optræder side om side i dette værk, og Grundtvig samtolker dem. Særlig berømt er citatet: "Høje Odin! Hvide Krist! / Slettet ud er Eders Tvist, / Begge Sønner af Alfader." Det er forståeligt, at Grundtvig ikke sendte bogen til sine forældre i Udby Præstegård - de ville ikke have fattet sammenstillingen af Gud og Odin. Denne fuldstændige jævnføring er da også enestående i Grundtvigs forfatterskab, men til gengæld slog den rod på forunderlig vis og har kunnet opleves langt op i tiden, især i friskolemiljøer, men også i folkeskolen. Jeg har selv oplevet den i svækket form i begyndelsen af 1950'erne, hvor min lærerinde fortalte nordisk mytologi to timer om ugen, og næste år i de samme to timer fortalte hun bibelhistorie ud fra Morten Pontoppidans klassiske fremstilling. Vi skolebørn glædede os meget til disse fortælletimer, og på vejen hjem sammenlignede og samstillede vi heltene og historierne: Hvem var stærkest? Var Samson, før han blev klippet, stærkere end Thor? Vidste Odin, takket være sine ravne, lige så god besked om alt muligt, som Gud gjorde? Og var Jesus lige så god som Balder? Den nordiske gudeverden og kristendommen var for os blevet til to helt ligeværdige forestillingsverdener.

Samme år som Maskeradeballet udkom Nordens Mytologi, hvor Grundtvig vælger at fortolke de nordiske myter som én stor sammenhæng, et udtryk for en verdensorden på samme vis som kristendommen, og Kristus var blot en renere søn af Alfader end Odin (Holm 2001, 16-17). Værkets undertitel er karakteristisk: Udsigt over Eddalceren for dannede Moend, der ei selv ere Mytologer. Den forklarer indirekte, hvorfor Nordens Mytologi ikke fik den tilsigtede virkning. Ganske vist var bogen en introduktion til den nordiske gudelære, der var med til at bringe nogen orden i et hidtil næsten uoverskueligt materiale. Men Grundtvig ville ikke nøjes med at give en historisk fremstilling for dannede mænd, han ville også fortolke myterne for ikke-mytologer og vise, hvorledes mytologi og kristendom forholdt sig til hinanden, og endelig ville han også give en overordnet forståelse af de nordiske myter. Alle de attributter, som man normalt forbinder med de nordiske guder - lige fra Thors hammer til Frejas rok - var skildret som noget senere tilkommet uden større betydning. Det bevirkede, at Nordens Mytologi ikke blev et særligt billeddannende værk, og bogen fik derfor ikke den tilsigtede virkning. 
Efter freden i Kiel i 1814 med tabet af Norge skrev Grundtvig Thryms Kvide, som udkom i 1815. Det var en skildring af ranet af Thors hammer Mjølner med tydelige paralleller til Sveriges anneksion af Norge. Værket sluttede med en formæling mellem Thor og Freja, som ganske vist er helt uden baggrund i myterne, men det var en storslået vision om Norges genforening med Danmark. Grundtvig bruger her mytologien i nationalpolitikkens tjeneste. Denne frisættelse af mytologien fra den videnskabelige spændetrøjes krav er kommet til at præge eftertidens brug af mytologien langt op i det 20. århundrede, hvor Trymskviden i Grundtvigs fortolkning er blevet en af de mest populære af de mytologiske fortællinger overhovedet.

I 1832 udgav Grundtvig Nordens Mythologi eller Sindbilled-Sprog historisk-poetisk udviklet og oplyst, der var en helt omskrevet udgave af hans mytologi fra 1808. Grundtvig havde ikke længere dannede mænd som sin målgruppe, men skrev nu for at vække det danske folk til erkendelse af dets danskhed, og han ville anskueliggøre denne folkeånd som en del af den fællesnordiske. Myterne bliver her grundlæggende fortolket som sindbilleder, det vil sige sanselige udtryk for abstrakte fænomener som for eksempel menneskets længsler. Bogen havde det aktuelle sigte at skabe en ny form for dannelse med basis i den nordiske kulturarv, og den nordiske mytologi fremstår som et bevis på, at der er en selvstændig nordisk folkeånd (Auken 2005, 349). Det betød, at mytologiens aktuelle udtryksmuligheder var væsentligere for Grundtvig end dens oprindelige mening. Det afgørende var således myternes opildnende kraft og gavnlige brug, ikke deres religiøse funktion. Ved at fremstille myterne ikke som en religion, men snarere som et udtryk for livsopfattelsen hos de nordiske hedninger, blev der givet frit spil for den mytefortolkning, der kom til at præge ikke blot de grundtvigianske højskolemiljøer, men store dele af den danske offentlighed igennem det næste århundrede. Nordens Mythologi blev i sidste halvdel af 1800-tallet med Sune Aukens ord til et kanonisk skrift i den danske højskoleverden (Auken 2005, 485).

Imidlertid fik den nordiske mytologi ikke umiddelbart en stor gennemslagskraft i offentligheden, som Grundtvig havde håbet på. Det blev klart, da der efter afslutningen af Første slesvigske Krig skulle laves et monument over det sejrrige udfald fra Fredericia i 1849. H. V. Bissen indsendte en skitse af en menig soldat, der løftede en bøgegren som sejrssymbol, tilsyneladende helt i Grundtvigs stil og ånd. Men Grundtvig forkastede dette og pegede i stedet på et andet forslag fra Bissen med Uffe hin Spage. Han endte dog med at lægge sig i selen for et helt tredje forslag med den kampklare Thor, og det var lavet billedhuggeren J. A. Jerichau (Lundgreen-Nielsen 1992, 118 ff.; Adriansen og Jenvold, $58 \mathrm{ff}$.). Det blev imidlertid Bissens forslag med den tapre menige landsoldat, der vandt afstemningen og som blev realiseret og vandt virkelig folkeyndest. 
Denne sag er symptomatisk for Grundtvigs forsøg på at skabe et nordisk-mytologisk billedsprog. Flemming Lundgreen-Nielsen har karakteriseret det som et mislykket eksperiment i sin afhandling herom (Lundgreen-Nielsen 1994). Det er rigtigt for Grundtvigs levetid, men ser vi på virkningshistorien, er eksperimentet næppe helt så mislykket, i hvert fald ikke for heltenes vedkommende. Fortællingerne om guder og helte har været i flittig brug gennem 1800- og 1900-tallet og er blevet anvendt til ideologiske formål - både i folkeskolen og i politik af partier med meget forskellige ideologier.

Det var hovedsageligt som litterære symboler, at den nordiske mytologi slog igennem, kun i ringe grad som billeder og slet ikke som skulpturer. Men hvis det var sket, ville Grundtvig næppe have været ret begejstret for det, for han regnede billedkunsten for den ringeste af alle kunstarter - ordet i mundtlig og skriftlig form stod naturligvis øverst. Sagnene om de danske helte spillede en mindre rolle i Grundtvigs forfatterskab end fortællingerne om de nordiske guder. Han lagde hovedvægten på guderne, og i hans mytologiske hovedværk fra 1832 er der således kun sporadisk omtale af heltene.

Det kom til at ændre sig efter udbruddet af Første slesvigske Krig i 1848 , hvor de to sønner Johan og Svend Grundtvig meldte sig som frivillige krigsdeltagere. Også Grundtvig meldte sig til krigstjeneste, men med på de indre linjer med henblik på styrkelse af nationens kampvilje og modstandskraft. Det skete gennem grundlæggelsen af tidsskriftet Danskeren, som han udsendte hver uge 1848-1851, og hvori han stort set skrev alle bidrag selv. Her træder, som LundgreenNielsen har udtrykt det, alle Grundtvigs ideer om danskhed i handlende karakter for at stå deres prøve i krigens virkelighed (Lundgreen-Nielsen 1992, 93). Kun en halv snes dage efter krigsudbruddet tryktes i Danskeren en "Slesvigsk-Dansk-MindeSang", der skildrer en af de berømte episoder i Saxos Danmarkskrønike. Det er historien om kong Vermund den Gamle og sønnen Uffe hin Spage, der mandede sig op i sidste øjeblik, da landet stod i den yderste fare for at blive overtaget af tyskerne:

Og Uffe, han stod nu mod Tydskere to

I Holmgang, hvor Eideren strømmer,

Og Vermund den Gamle, han græd og han loe

Som Barnet, der underfuldt drømmer!

(...)

$\mathrm{Nu}$ Tydskerne begge laae døde som Sild,

Og Uffe stak Sværdet i Skede,

Og Rygtet om Seiren, det foer som en Ild

Fra Eider i Nør over Hede!

(Danskeren, 1848, 79 f.)

Denne sang har været med til at skabe og fastholde et billede af den danske nation, der trues af den store nabo mod syd, "for lang er med 
Tydsken vor Trætte", men når en tøvende dansk helt i sidste øjeblik mander sig op og går ud i kamp, er lykken alligevel blid. Dette fjendebillede af den store nabo mod syd, der ville erobre Danmark, blev for de fleste danske bekræftet under de to slesvigske krige, og opfattelsen blev yderligere bestyrket af den måde, hvorpå den preussiske regering forvaltede styret i Nordslesvig efter indlemmelsen i 1867. Sangen om "Kong Vermund den Gamle" har været med i Folkehøjskolens Sangbog fra 1. udgave i 1894 til 17. udgave i 1989.

Uffe hin Spage er prototypen på en helt hos Grundtvig. Han ligner Holger Danske og Niels Ebbesen ved at være tøvende og sen. Men når de først vågner til dåd, er de ordholdende, effektive og tapre. Der er en udtalt mangel på stærkt handlende helte i den danske kulturhistorie, og Grundtvig må utvivlsomt tilskrives en del af æren herfor. I 1840'erne skabte grafikeren og maleren Lorenz Frølich et kongenialt billede af Uffe hin Spage, der er skildret netop i det øjeblik, hvor han sindigt stak sværd i skede. Billedet blev to generationer senere anvendt i Axel Olriks bog Danske Heltesagn, der blev udgivet i år 1900, kom i talrige oplag og blev en meget yndet højtlæsningsbog i danske hjem. ${ }^{4}$ Den blev også benyttet af lærere som grundlag for mundtlige fortællinger. Nogle af Frølichs illustrationer til heltesagnene blev også udsendt som xylografier, der kunne indrammes og ophænges i skolestuerne. I min jyske landsbyskole i 1950'erne hang Frølichs billeder af Uffe hin Spage og Skjold i skolestuen, og læreren henledte opmærksomheden på dem, hver gang vi sang Grundtvigs viser om disse to sagnkonger. Det at synge - samtidigt med, at man kigger intenst på en fængende skildring af den begivenhed, som sangen omhandler - er med til at skabe en stærk og virkelighedsnær oplevelse. At det havde udspillet sig på denne vis, kunne vi jo selv se.

Hvorledes mytologien fungerede $\mathrm{i}$ hverdagslivet på højskolerne $\mathrm{i}$ de første årtier, fremgår af dels samleværket Højskolens ungdomstid $i$ breve (1960), dels af Jens Peter Ægidius' undersøgelse Mytologi og folkehøjskole (1978). I 1979 udgav den svenske professor i litteraturvidenskab, Lars Lönnroth, en studie over den nordiske mytologi som politisk redskab i grundtvigiansk bonde- og højskolemiljø. Han formår ikke overbevisende at forklare, hvorfor vikingetidens nordiske myter pludselig blev brugbare i den politiske kamp, men hans redegørelse for forvaltningen af denne arv er ganske inspirerende. Lönnroth påviser, hvorledes den nordiske mytologis symboler ofte anvendes til at smykke facaden, selvom indholdet bag facaden end ikke strejfer den nordiske mytologi (Lönnroth 1979, 43 f.). Heimdal med sit gjallerhorn pryder således omslaget af en yderst tør og saglig redegørelse for danske andelsmejerier, der udkom i 1914. Og mange af datidens bondealmanakker var smykket med prægtige skjoldmøer, selvom de slet ikke indeholder bragesnak, men kun kalender, markedsoversigt og et par noveller inden for genren triviallitteratur. 

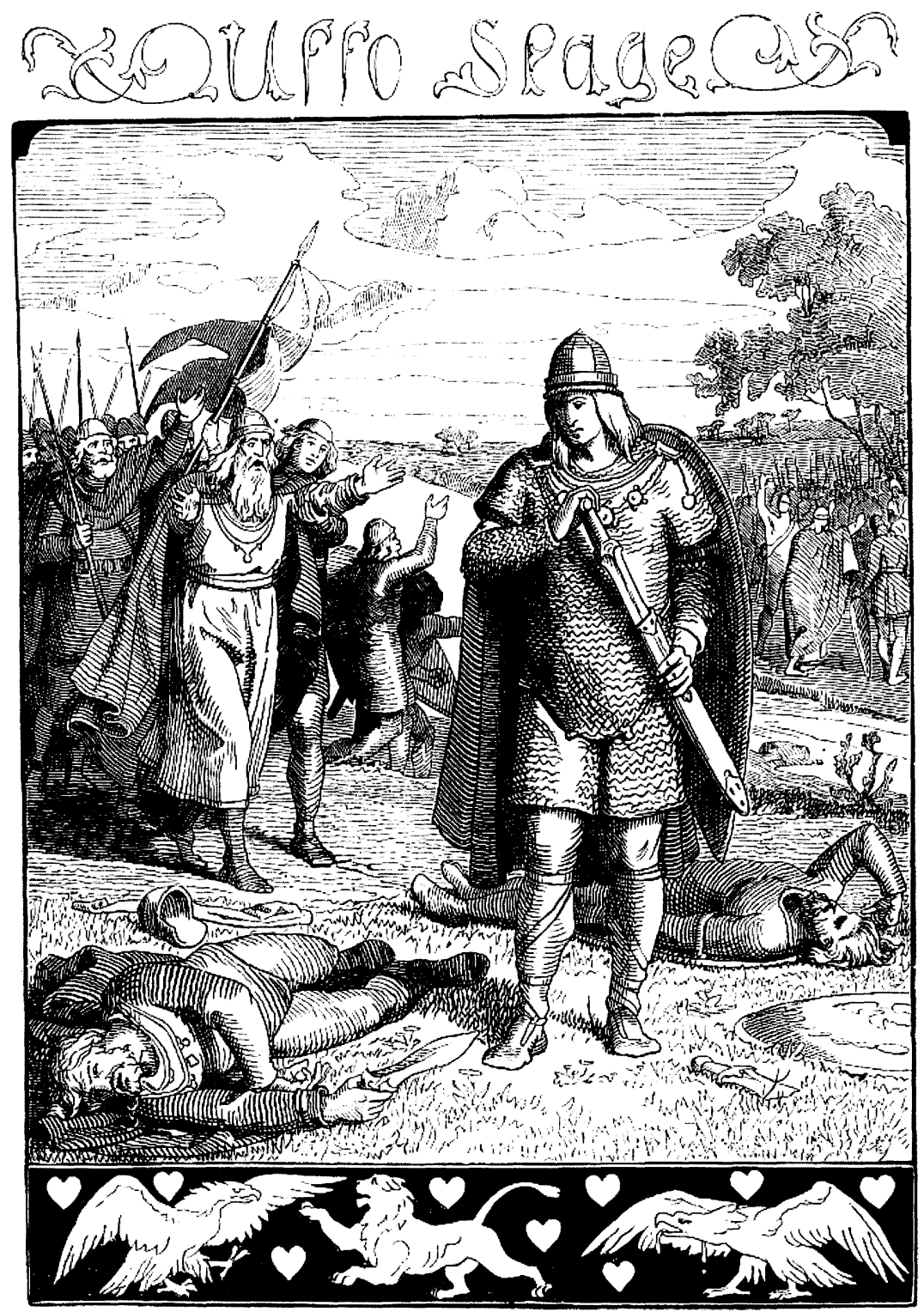

Lorenz Frølichs tegning af Uffe, der stikker sværdet i skeden efter at have fældet to tyske udfordrere, blev lavet til bogen Danske Heltesagn, udgivet af Udvalget til Folkeoplysningens Fremme i 1900. Det er den klassiske fremstilling af det populære sagn om Uffe, og billedet blev reproduceret og var udbredt ikke mindst i skoler. Det vakte derfor opstandelse, da den tyske sagnforsker Karl Müllenhoff hævdede, at Uffesagnet oprindeligt stammede fra England. 


\section{Englandskrigene}

Englandskrigene blev i høj grad igangsættende for Grundtvig. Københavns bombardement i 1807 havde som nævnt været med til at starte hans litterære produktion, og kampen ved Sjællands Odde året efter mellem et dansk orlogsskib og to engelske linieskibe, hvor hans Egeløkke-ven Peter Willemoes faldt, skildrede han i digtet "Kommer hid, I Piger smaae". Et par år senere skrev han indskriften på monumentet på Odden kirkegård, som blev bekostet af kaptajn Lorentz Fribert, en fjern slægtning af Grundtvig. Det er et klassicistisk monument i norsk marmor med en forstavn, værget af en køllebærende løve, der støtter sig til det danske rigsvåben. Mindestøtten er kronet af en hjelm og en krans af cypresser. Det er en form for "oldnordisk empire", og i den samme stilfærdige og dog højstemte stil har Grundtvig lavet indskriften:

De Snekker mødtes i Kvæld paa Hav,

Og Luften begyndte at gløde.

De leged alt over den aabne Grav,

Og Bølgerne gjordes saa røde.

Her er jeg sat til en Bavtasten

At vidne for Slægter i Norden:

Danske de vare, hvis møre Ben

Under mig smuldre i Jorden,

Danske af Tunge, af Æt og af Id,

Thi skal de nævnes i løbende Tid

Fædrenes værdige Sønner!

Poul Borum udgav i 1983 bogen Digteren Grundtvig. Han kalder heri dette digt for "hans første virkelige hit, som altid vil være på Grundtvigs top-ti-liste" (Borum 1983, 68). Søjlen i antik stil modsvares på fornem vis af indskriften, der indledningsvis meddeler facts om kampen i renfærdig prosa. Derpå kommer det her citerede digt, der først skildrer kampen og dernæst personificerer mindestøtten og til slut udtrykker eftermælet. I kraft af sin indskrift er dette et af de første nationale mindesmærker, som findes i Danmark. Det står i klar modsætning til helstatspatriotiske mindesmærker ved sin understregning af, at de faldne var danske af sprog, af herkomst og af gerning. Det er en monumental tekst, som både begivenheden og funktionen som gravmæle over helte lægger op til. Allegorierne er hentet fra den nordiske oldtid, og sprogtonen er værdighedsstiliserende. Linjeskibet og de to engelske fregatter bliver til snekker, og den klassicistiske søjle med anstrøg af empire fremstår som en bautasten, der skal vidne om fortidens bedrifter for nutiden og fremtiden.

Det er fremragende gjort, og måske er det blevet så virkningsfuldt 


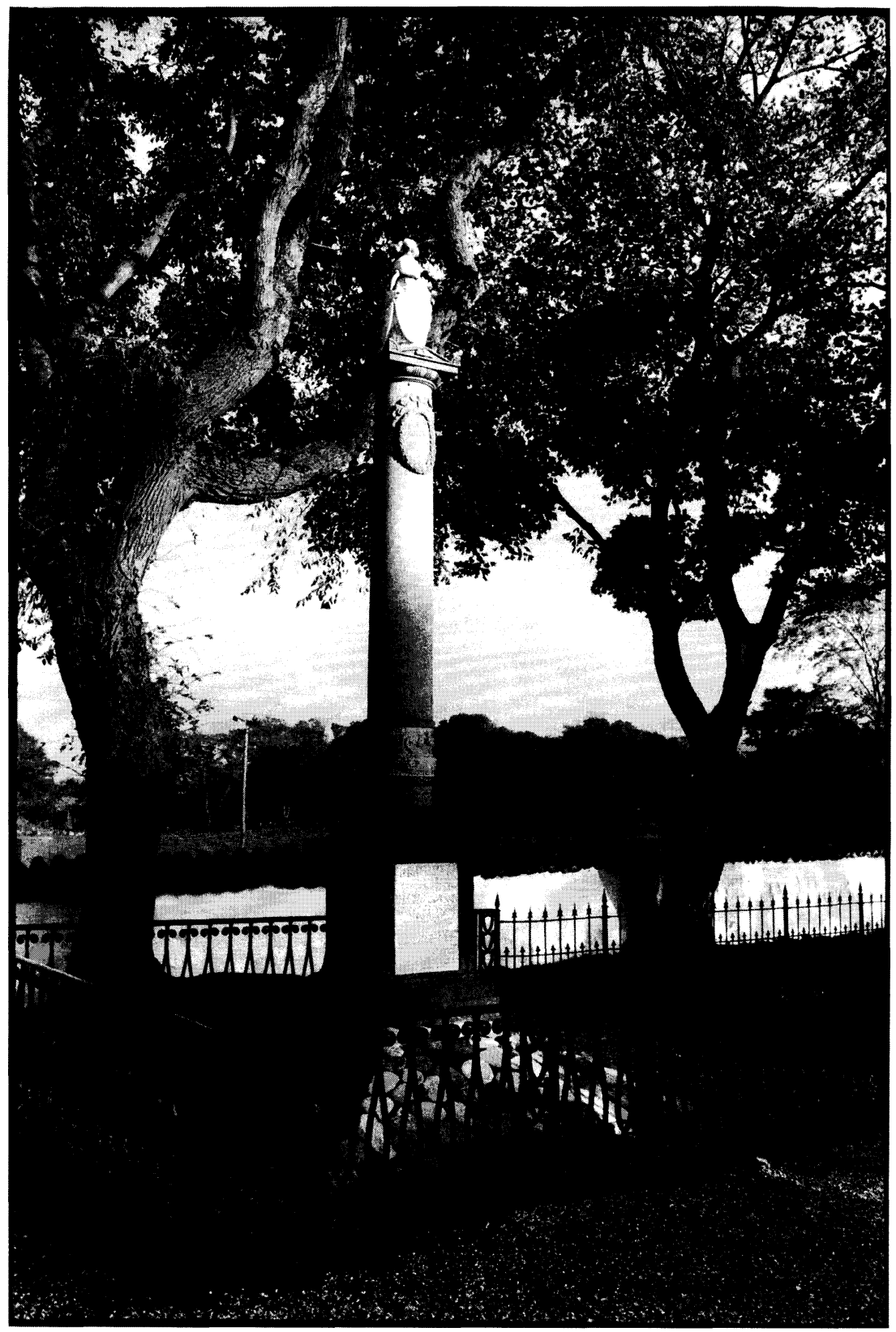

Mindesøjlen på Odden kirkegård blev rejst i 1810 på toårsdagen for kampen ved Sjællands Odde, hvor Grundtvigs ungdomsven Peter Willemoes faldt. Søjlen er i nyklassicistisk stil og prydet med en hjelm og en laurbærkrans. På postamentet er der den berømte indskrift $i$ oldnordisk sprogtone, forfattet af Grundtvig i 1809 på opfordring af den kaptajn, der bekostede monumentet. (Foto: John Jedbo, Det Kongelige Bibliotek.) 
og overbevisende, fordi der her var noget på spil. Digtet afspejler jo også Grundtvigs livsprojekt. Han var også dansk af sprog, og af æt og id, og han følte sig kaldet til at vidne for samtiden og fremtiden om danskheden. Grundtvigs digt forener på forbilledlig vis en nordisk sprogtone med et klassisk billedsprog, og indskriften på Odden Kirkegård var, sammen med sangen om Peter Willemoes, medvirkende til at fastholde Englandskrigene som en af de identitetsskabende begivenheder i danmarkshistorien. Dette oplevede Grundtvig selv, da han sejlede hjem fra den store Skamlingsbanke-fest i 1844, hvor han havde været hovedtaler. Om bord på dampskibet var der talrige festdeltagere, og da skibet passerede Sjællands Odde, sang den nationalt opstemte ungdom spontant visen om Willemoes, og derpå mindede Grundtvig om, "hvad der staaer paa Bauta-Stenen over ham og de andre Ænherier og Medbeilere til Livet i Valhall og Folkvang: i Heltedigtet og i Kæmpevisen”, og han udbragte et lykkeligt hurra til deres ihukommelse (Johansen \& Høirup 1983, 77).

\section{Dannevirke og Dannebod}

Fra 700-tallet til 1200-tallet udbyggede de danske konger Dannevirke som rigets værn mod syd, men derpå mistede det store voldanlæg sin betydning. Det skyldtes især to forhold, dels blev den lidt sydligere grænseflod Ejderen fastlagt som rigets grænse, dels mistede også denne nye grænsedragning hurtigt sin betydning, fordi Slesvig og Holsten i stigende grad blev styret sammen. De efterfølgende seks hundrede års udvikling i hertugdømmerne formåede dog ikke helt at udviske forestillingen om Dannevirkes betydning som rigets vold og værn. I begyndelsen af 1800-tallet blev Dannevirke "genopdaget", først som kulturelt og politisk symbol, dernæst som forsvarsværk og arkæologisk anlæg.

Grundtvig var medvirkende til at skabe interesse for Dannevirke. I perioden 1816-1819 udgav han tidsskriftet Danne-Virke, som skulle tjene til at vække og styrke fædrelandskærligheden. Navnet blev valgt, fordi Grundtvig ud fra sine Saxo-studier opfattede volden som et sindbillede på den danske konges magt og beskærmelse af sit folk, og siden hen som et billede på folkets forsvarsvilje. Som programerklæring for det nye tidsskrift anførte Grundtvig en strofe af digtet "Efterklang" til "Norne-Giæst (et Skiemtesagn)":

Klokken i den danske Kirke,

Det er Sagas klingre Skjold,

Til at bygge Danne-Virke

Vække den hver Dane bold!

Ret den klinger dog i Vangen,

Kun i Chor med Kirkesangen,

Under Thyra Dannebod ( $D V \mathrm{I}, \mathrm{I})$. 
Strofen blev anført på titelbladet ikke blot på den første, men også de øvrige tre årgange af tidsskriftet, og det viser den betydning, Grundtvig må have tillagt den. Helge Toldberg anfører i sit værk Grundtvigs Symbolverden, at denne strofe rummer nøglen til Grundtvigs folkelige virke. Grundtvig følte det som et kald, som han ikke kunne undslå sig for, at fremlægge alt sit fædrelandshistoriske materiale, så samtiden kunne lære at forstå sig selv i lyset heraf (Toldberg 1950, 210). Tidsskriftet Danne-Virke skulle være et forum for en aktiv vækkelse af det danske, og Sagas, det vil sige historiens, skjold fremstår her som den danske kirkeklokke. Grundtvig slog til lyd for opbygningen af et åndens Dannevirke, hvor plejen af dansk kultur skulle være et effektivt værn mod den centraleuropæiske og tyske indflydelse. Han ville skabe en oplyst, kristen danskhed, der byggede på kulturarven (for at bruge et nutidigt begreb). Også $\mathrm{i}$ andre digte fremstod oldtidsvolden som et symbol på dansk styrke, for eksempel i en salme fra 1826, hvor Grundtvig anvendte Dannevirke som et billede på den danske kirkes urokkelighed, styrke og ærværdige alder: "Tusind Aar stod Christi Kirke / Paa sin Klippe blandt os trygt. / Tusind Aar vort Dannevirke/ Var den mod al Fiendens Frygt."

Tidsskriftet Danne-Virke udkom i 4 år og indeholdt især videnskabelige, tanketunge afhandlinger, der just ikke var lettilgængelige. Det samme gælder de såkaldte efterklangsdigte, der rummer en særlig vekselvirkning mellem fortid og nutid. ${ }^{5}$ Men centrale begreber fra Grundtvigs senere forfatterskab, som for eksempel danskhed, folk, folkeånd og det levende ord, blev præsenteret i deres første form her (Thodberg og Pontoppidan Thyssen 1983, 11). Tidsskriftets udbredelse og læserkreds kendes ikke, men dets titel afspejler, hvorledes Grundtvig - også her - formåede at foregribe noget, der senere skulle blive en folkelig sag: Det forhistoriske forsvarsværk Dannevirke blev til et symbol på den danskhed, der blev truet sydfra. Grundtvigs centrale tese om nødvendigheden af et åndeligt Dannevirke blev forstået - for et par årtier senere blev Dannevirke igen brugt som bladnavn, denne gang som betegnelse på den første dansksprogede avis i Slesvig. ${ }^{6}$

I bladets titelvignet indgik et billede af Dannevirke med vold og vagttårn med de slesvigske løver som murdekoration og et vajende Dannebrog fra tårnet. Foran Dannevirke var anbragt en runesten med ordet Danmark indgraveret. Også den valgte dato til udgivelse af det første hæfte vidner om anvendt nationalsymbolik. Det første nummer af bladet Dannevirke var dateret 15. juni 1838, selvom bladet først udkom fem dage senere. Datoen var valgt og blev fastholdt, fordi det var den såkaldte Valdemarsdag, både datoen for Arkonas indtagelse i 1169 og Slaget ved Reval i Estland i 1219. Bladet Dannevirke begyndte - ligesom Grundtvigs tidsskrift Danne-Virke - med en programerklæring på vers, som knyttede oldtid og nutid nært sammen. 


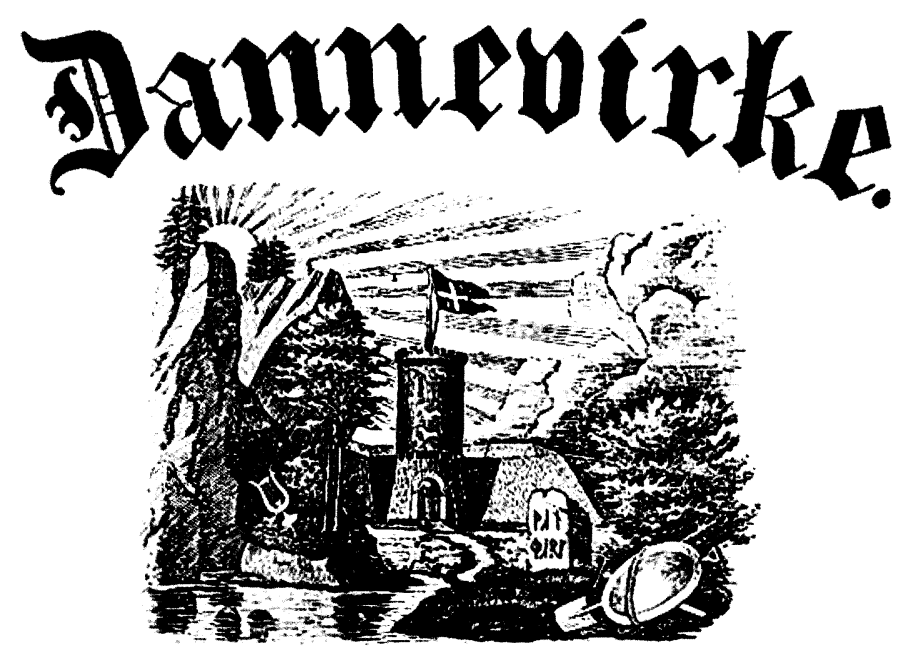

Ct Hgeblas for Gertugoómmet Elesvig. No9. Den 16. QAuguip. 15:34.

Ugebladet Dannevirke blev grundlagt i Haderslev 1838 og blev efter nogle år til et dagblad, det første dansksprogede $i$ hertugdømmet Slesvig. Bladet skulle i lighed med Dannevirke værne om danskheden. Titelvignetten symboliserede dansk styrke med og forsvarsvilje (skanse, borgtårn, sværd og skjold), danskernes historiske ret (runesten med ordet Danmark) og troen på fremtiden (Solen, der forjager de truende skyer). (Foto: Museum Sønderjylland - Sønderborg Slot.)

Den nye dansknationale bevægelse blev her skildret som et forsvarsværk i lighed med oldtidens Dannevirke - og det afspejler fuldkommen Grundtvigs forestillinger om det nationale.

Nært forbundet med Dannevirke er myten om dronning Thyra som den første, der tog initiativ til opførelsen af grænsevolden. Grundtvig kendte beretningen om dronning Thyra fra Saxo og Sven Aggesens danmarkshistorier. Ganske vist er den ældste del af Dannevirke opført 300 år før Thyra og Gorm den Gamle var regenter, men den viden havde man ikke i 1800-tallet, og forestillingen om den aktive landsmoder, der opildnede sit folk, må have tiltalt Grundtvig. Fra Peder Syvs folkevisebog, der udkom i 1695, kendte Grundtvig en vise om Thyra, og den bearbejdede han i flere omgange, det samme gjorde Oehlenschläger, men det er Grundtvigs bearbejdelser af den, som er blevet udbredt. ${ }^{7}$ Medvirkende hertil var også en meget sangbar melodi, der blev komponeret i 1811: 
Danmark, dejligst Vang og Vænge,

Lukt med Bølgen blaa,

Hvor de voksne danske Drenge

Kan i Leding gaa

Mod de Tyske, Slaver, Vender,

Hvor man dem paa Tog hensender;

Én Ting mangler ved den Have:

Ledet er af lave.

Saadan talte Dronning Thyre,

Ret kaldt Dannebod:

I, som staa for Danmarks Styre,

Fatter freidigt Mod!

Gabet kan vi vel tillukke,

Saa vi ej os lader plukke

Af hver fremmed Løbeskytte,

Der faar Lyst til Bytte. ${ }^{8}$

Visen fortæller, hvorledes dronning Thyra kaldte alle bofaste mænd i riget sammen og befalede dem at bygge en vold til værn mod fjenden. Med visens ord: "Hvo sig for en dansk vil kende, / møde der med Vogn og Heste / Volden at befæste." Beskrivelsen af Dronning Thyra svarer både til de norrøne skjoldmøer og til den Mor Danmark-skikkelse, Dana, som Grundtvig også var med til at udvikle. Dannebod-visen i Grundtvigs version blev sunget til de store danske folkemøder på Skamlingsbanken i 1840'erne og blev trykt i en skolesangbog i 1847 (Adriansen 2003, bd 2, 200 ff og 447 ff.). Året efter blev visen sunget af det folkeoptog, som den 21. marts 1848 gik gennem København til Christiansborg for at anmode kongen om en fri forfatning og Slesvigs forbindelse til kongeriget styrket. Den store folkeskare sang Danebod-visen med en inderlighed og styrke som en salme i en fyldt kirke, har en af deltagerne berettet. Ved udbruddet af Treårskrigen i april 1848 blev Dannebod-visen sammen med en ny dansk krigssang udsendt som skillingstryk til de danske soldater. Den fik en opildnende effekt $\mathrm{i}$ kraft af sine forførende fjendebilleder og den velklingende, sangbare melodi. Grundtvig skrev selv om visen, at den var "i det Hele saa herlig, og baade først og sidst saa usigelig deilig, som kun Dannemænd kan føle" (US III, 395).

\section{Modersmålet}

Fra midten af 1700-tallet blev der udviklet en sprogpatriotisme, men sproget var dog ikke et tema for fædrelandssange før i 1837. Dette gælder også for de 59 sange, der blev skrevet $i$ anledning af en nationalsangskonkurrence i 1818, selvom nogle digtere havde medtaget en enkelt strofe om sproget. Det samme gjorde Grundtvig i sin lejlighedssang "Langt høiere Bjerge" i 1820: 
Langt høiere, ædlere, finere Sprog

Skal findes paa Fremmedes Tunge;

Om Høihed og Deilighed Dannemænd dog

Med Sandhed kan tale og sjunge;

Og træffer vort Modersmaal ei paa et Haar,

Det smelter dog mere, end Fremmedes slaaer!

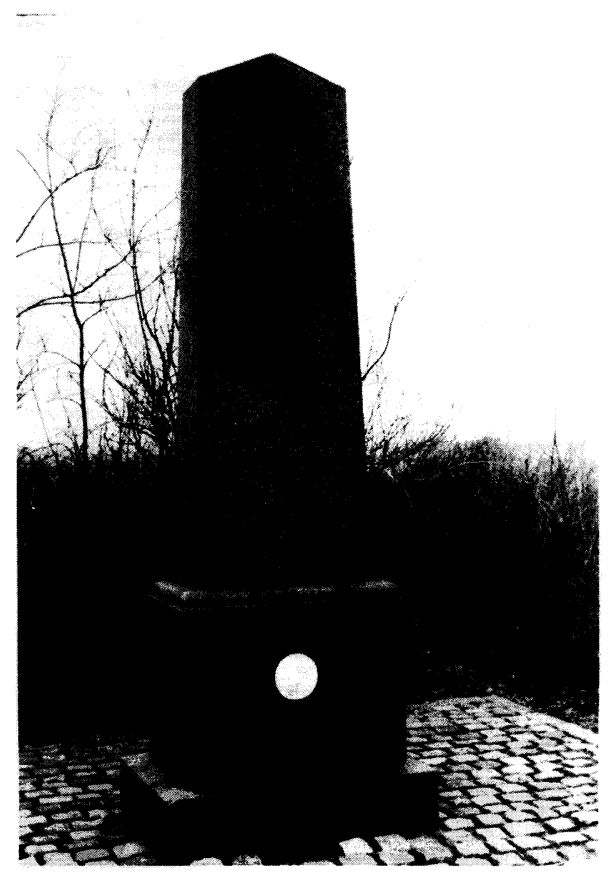

Mindestøtten over Grundtvig var det første af de talrige mindesmarker, der er blevet rejst på Skamlingsbanken, det nationale mødested lige nord for den dansk-tyske grænse af 1864 . Nordiske højskolefolk tog initiativ til mindesmarket i 1884 i anledning af $\mathbf{4 0}$-året for Grundtvigs berømte tale ved Skamlingsbanke-festen i 1844. Bestyrelsen for Skamlingsbanken ville imidlertid ikke at afholde folkefester på banken efter $1864 \mathrm{og}$ ønskede en afsløring $\mathrm{i}$ al stilhed. Men der kom uventet 1500 personer, og ved denne lejlighed besluttede man at genoptage de store folkemøder på banken - helt i Grundtvigs ånd. (Foto: Museum Sønderjylland - Institut for Sønderjysk Lokalhistorie.)

Grundtvig nævner det kun som en mulighed, at andre sprog kan være mere udviklede; han pointerer modersmålets evne til enkelhed, gør dets svaghed til positiv fortrolighed og får fremmedsprogenes styrke til at fremstå som hårdhed (Lundgreen-Nielsen 1982). Den første fædrelandssang, der udelukkende havde sproget som tema, blev skrevet i 1837, og det var igen Grundtvig, der var på spil. Lige før 
nytår digtede han "Moders Navn er en himmelsk Lyd", og ifølge traditionen skulle det være sket i glæde over, at den censur, som han var været under som følge af en injuriedom, uventet var blevet ophævet. ${ }^{9}$ Denne tradition har aldrig kunnet verificeres, ${ }^{10}$ og den er et eksempel på de myter, der blev knyttet til Grundtvigs liv og virke, efter at han var blevet kultfigur. ${ }^{11}$ Men uanset hvad baggrunden for sangen om modersmålet er, så er det de høje toner på strengene, der her bliver rørt:

Modersmaal er det Rosenbaand,

Som Store og Smaa omslynger,

I det lever kun Fcedres Aand,

Og deri kun Hjertet gynger.

Modersmaal er vort Hjertesprog,

Kun løs er al fremmed Tale,

Det alene i Mund og Bog

Kan vække et Folk af Dvale. ${ }^{12}$

Modersmålet er her ligesom hos Luther det fælles sprog, der kan bruges både til evangeliet og til folkelig brug. Som i næsten alle nationale bekendelser er der også en modsætning til noget fremmed, men det er kun diskret antydet. Med denne sang ophøjede Grundtvig modersmålet til et nationalt symbol og gjorde sproget til et vigtigt tema for fædrelandssange. Mange andre tog denne tråd op, ikke mindst i Slesvig, hvor sprogtemaet er blevet dyrket særlig intensivt af sangskrivere (Adriansen 2003, bd. 2, 49 ff).

\section{Fadrelandssange}

Den nationale fællessang, som har været et uundværligt element $\mathrm{i}$ danske folkelige forsamlinger, opstod i forbindelse med Grundtvigs offentlige forelæsninger "Mands Minde". Disse forelæsninger blev afholdt på Borchs Kollegium i København i 1838, da censuren over ham var blevet ophævet. Her fortalte Grundtvig det sidste halve århundredes historie ud fra sine egne oplevelser. Den 17. oktober fortalte han om Englandskrigene og Peter Willemoes, der blev berømmet for sit mod og fremstod som legemliggørelse af kærlighed til fædrelandet. Grundtvig sluttede sit foredrag med at fortælle om kampen ved Sjællands Odde og citere sin indskrift på mindestøtten. Der var helt stille, da Grundtvig tav, men så kom der et uventet efterspil på foredraget, som bevirkede, at denne dag, 17. oktober 1838, ofte omtales som den folkelige fællessangs fødselsdag (Bak 1977, 22). Tilhørerne begyndte spontant at synge "Kommer hid, I Piger smaae!" som et genmæle på det fremførte. En af tilhørerne, Frederik Barfod, skrev allerede dagen efter en lang, begejstret artikel til Kjøbenhavnsposten om foredraget og den vekselvirkning med sang, com har var hlavat nroliticarat 


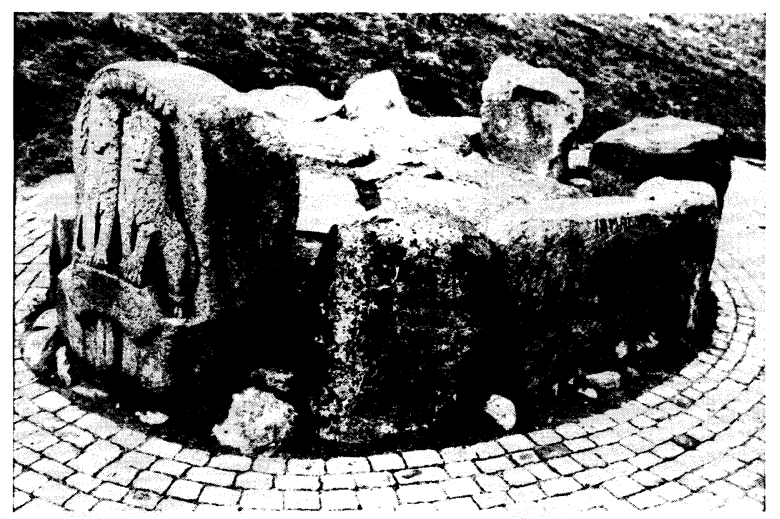

Talerstolen på Højskamling med citat af Grundtvig. Her mødes en særegen blanding af det nationale, det kristne og det oldnordiske. Forrest sidder de to slesvigske løver ovenpå en thorshammer, hvori der er indhugget en fisk som kristent symbol. På næste sten er citatet: “Ordet det Guddoms-Underværket / det er Folke-Kendetegnet”. Og på den tredje side er navnene på de fremtrædende mænd, der talte ved de to forste folkefester på Skamling, bl.a. Grundtvig, Orla Lehmann, Meïr Aron Goldschmidt og Laurids Skau. Bag talerstolen er plantet træer fra de nordiske lande: en bøg, en gran, en birk. Med et håndfast symbolsprog anskueliggøres her modersmålet, historien, kristendommen, kærlighed til fæedrelandet og skandinavisme. Talerstolen er udført i 1903 af Niels Larsens Stevns efter tegning af Lorenz Frølich. (Foto: Museum Sønderjylland - Institut for Sønderjysk Lokalhistorie.)

De fleste af tilhørerne var akademikere eller studenter, der kom fra dannede hjem i København og havde givetvis ofte sunget og spillet. Men dette var ikke en sang, der skulle opleves fra tilskuerbænken eller opføres for et publikum. Her var hverken kunstner eller publikum, og man sang ikke for hinanden, men med hinanden ud af den samtidige virkelighed. Det har tilsyneladende virket både selvfølgeligt og snublende nært, og der er næppe grund til at betvivle Barfods begejstrede beskrivelse, da en af de øvrige tilhørere, Carl Joakim Brandt, gik hjem og beskrev samme hændelsesforløb i et brev til sine forældre.

Det er både rigtigt og forkert at sige, at den folkelige fællessang fødtes ved denne lejlighed. Det er rigtigt, at det var noget nyt og epokesættende, at der opstod en vekselvirkning, således at fællessang blev et gensvar på det talte (og levende) ord. Det betød dog ikke, at alle foredrag fra da af blev indledt eller afsluttet med fællessang, men spiren var lagt til en skik, der blev til en livskraftig tradition med store virkninger på det folkelige område (Bak 1977, 23).

Traditionen med at synge fædrelandssange gruppevis ville givetvis 
også have fået et gennembrud uden denne episode, da den hænger nøje sammen med den kulturelle og politiske udvikling i Danmark. Men der er ingen grund til at betvivle Grundtvigs store betydning for udviklingen af en særlig dansk tradition for afsyngelse af fædrelandssange i forbindelse med foredrag og vækkende taler. Hans betydning er meget markant i kraft af de talrige sange, han har skrevet. På dette tidspunkt var grundtvigianske skolefolk og præster allerede begyndt at bruge de nye fædrelandssange i tilknytning til deres undervisning og folkelige foredrag.

\section{Nationen i moderskikkelse}

Forestillingen om fædrelandet som en skjoldmø og som et sindbillede på danskhedens kvindelige princip har Grundtvig dyrket gennem årtier. I Heimdall fra 1816 er der et programdigt med titlen Til Dana og Fadrene-Aaret, der skildrer Danas længsel efter himmelguldet. I digtet Nyaars-Morgen fra 1824 spiller 'Vor Moder' en helt central rolle. Det er et af de dunkleste, sværeste og oftest fortolkede værker af Grundtvig, og senest har Sune Auken fremlagt en ny og overbevisende læsning af det (Auken 2005, 352-465). Her er der kun grund til at nævne nogle få af Vor Moders karakteristika i Nyaars-Morgen. Hun har varme i brystet og kærmindeblå øjne og ledsager Grundtvig med på en rejse, der er bygget over Saxos sagn om Hading. Rejsen går både tilbage $\mathrm{i}$ tiden og frem mod de levendes land. Til sidst bliver de standset af en ismur. Efter flere forgæves forsøg på at komme over muren vrider Vor Moder halsen om på en hane og kaster den over muren. Her galer hanen og basker med vingerne, og ismuren begynder at smelte. Dette offer, måske et billede på Kristi død, får muren til at forsvinde og dagen til at bryde frem. De er nået til de levendes land, og Grundtvig fremstår fra nu af som Vor Moders søn og hendes talerør til samtiden. I hende sammenfattes, hvad det danske folk har brug for: mytologi, kristendom og historie, og disse elementer må ikke stå i vejen for hinanden.

Sindbilledet med Vor Moder indgår også i det magtfulde digt "Fæderneland! / Ved den bølgende Strand", der oprindeligt blev konciperet i august 1844 i en tid præget af danskfolkeligt røre, stigende slesvig-holstensk modstand mod dansk styre og kongelig vankelmodighed. Grundtvig svingede mellem dyb angst og fortvivlet håb, og i digtet gav han udtryk for sin tro på folkets genfødelse og fædrelandets frelse ved Guds kraft. Digtet blev ikke trykt, og det kunne derfor om- og tildigtes i maj 1848 efter udbruddet af 1 . slesvigske krig. To af Grundtvigs sønner havde meldt som frivillige i denne borgerkrig, hvor de slesvig-holstenske oprørere fik støtte af kongeriget Preussen. Den nære forbindelse mellem Slesvig og Danmark var truet, men Grundtvig havde en fast tro på, at Gud havde 


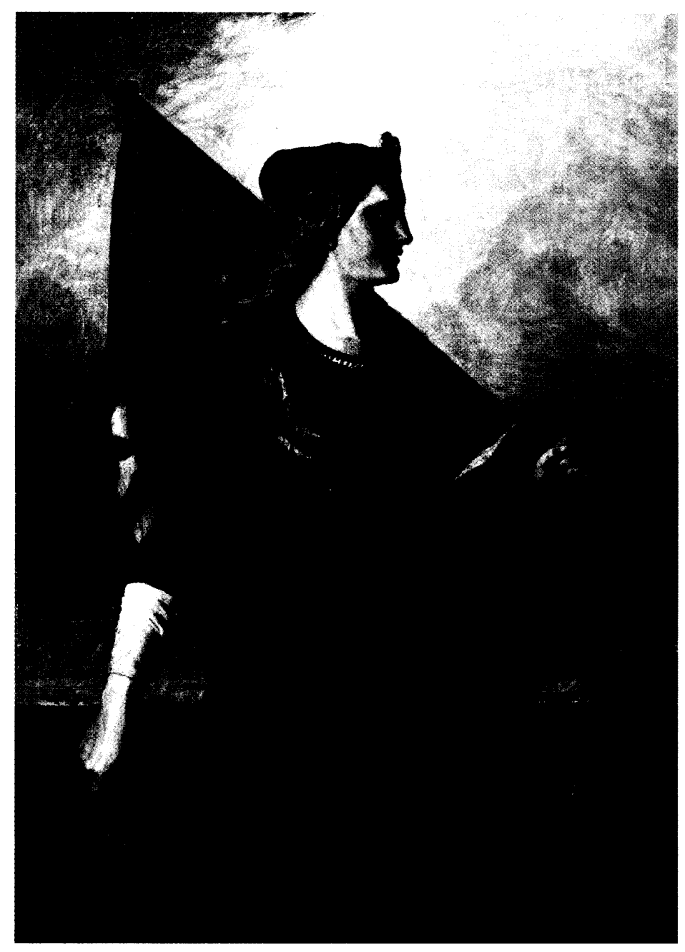

Elisabeth Jerichau Baumann: Danmark. Billedet af den danske nation som en ung stærk kvinde vandt stor yndest og blev reproduceret $i$ talrige udgaver. Det er malet 1850-1851 under indtryk af slaget ved Isted og Grundtvigs nationale digtning. Den tyskfødte malerinde var i 1849 flyttet til Danmark, hvor hun blev meget Grundtvig-begejstret og fik et venskabelig forhold til hans anden hustru, Marie Toft. Jerichau Baumann yndede at optrade med at synge sange og salmer af Grundtvig. (Foto: Museum Sønderjylland - Sønderborg Slot.)

en særlig hensigt med Danmark i verdenshistorien. Denne urokkelige tillid afspejler sig i den omdigtede version af "Fæderneland", hvor Grundtvig retter sin tale direkte til Danmark i skikkelse af en historisk ånd, der er indhyllet i sorg. ${ }^{13}$ Men Gud står bi, for Danmarks fjender er også hans fjender, og "end lever den Gamle af Dage". I den sidste strofe fremstår fædrelandet som en ung kvinde: "midt i Bølgerne blaa / Skal du blomstrende staae / Med din Mai og med dine Kiærminder, / Som en Mø med letrødmende Kinder". Med en melodi af H. Nutzhorn fra 1863 er dette digt blevet til en folkelig sang. Med sin karakteristiske sammenkædning af danskhed og kristendom har sangen vundet stor udbredelse og bevaret sin kraft langt op i det 20 . århundrede og har herved fastholdt billedet af danskheden som en ungmø med letrødmende kinder og blå kærminder.

Også i “Kiærminde-Sang”, som er digtet lige efter slaget ved Isted 
i juli 1850 skildrer Grundtvig nationen som en smuk ung kvinde, og få måneder senere genbruger han dette symbol i det store mærkelige digt fra eftersommeren 1850, "Danmark om hundrede Aar". Her beskriver Grundtvig to syner for fædrelandets fremtid. I det første ville Danmark blive helt opslugt af tysk kultur, mens landet $\mathrm{i}$ den anden vision - et stort profetisk fremtidssyn - vil overleve, og folkeånd og modersmål ville blomstre:

\section{Og Danskernes Maal er som Dannekvinden, \\ Vidunderlig øm og dog stærk i Løn, \\ Med Roser ei ene paa Ungdoms-Kinden, \\ Med Ild ei alene i Kys og Bøn: \\ Med Skjoldmøens Rødme i ædel Harm, \\ Med Heltemods-Ild i sin Skjoldmø-Barm!}

Digtet blev offentliggjort i tidsskriftet Danskeren 14. september 1850, og det er efter alt sandsynlighed denne beskrivelse af Danmark som en ung, smuk, stærk kvinde, der har været inspiration for den unge indvandrer, den tyskfødte malerinde Elisabeth Jerichau Baumann, der udførte et stort maleri, med titlen "Danmark". Hun var Grundtvigbegejstret og havde en god kontakt til Marie Toft, senere Grundtvigs anden hustru. I efteråret 1850 påbegyndte hun et maleri, der var en fuldstændig illustration af Grundtvigs slutstrofe i "Danmark om hundrede Aar" om Dannekvinden med roser på kind og heltemod i barm. Dette maleri fik en usædvanlig stor gennemslagskraft og har været med til fastholde forestillingen om fædrelandet i skikkelse af en stærk og dog varm kvinde frem til nutiden (Adriansen 1987).

\section{Kulturlandskabet}

Det Danmarksbillede, som er på nethinden hos mange af nutidens danskere, er skabt af guldaldermalere, blandt andet J. Th. Lundbye, P. C. Skovgaard, Lorenz Frølich, Thorvald Læssøe og Constantin Hansen. De følte sig som en gruppe, og værdifællesskabet kom til udtryk den nat i 1839, hvor Frederik VI døde, hvor de gav hinanden håndslag på at ville vie deres kunst til fødelandets pris med billeder " $\mathrm{i}$ simple hjertelige træk" (Henschen, Melander \& Miss 1994, 25). Det var J. Th. Lundbye, der formulerede opgaven således. Hans ord har klang af Grundtvig, og det er ikke tilfældigt, for flertallet af dem var grundtvigianere. De flokkedes om Grundtvig, lyttede til hans prædikener i Frederikskirken på Christianshavn og Vartov og til hans foredrag i Danske Samfund i 1840 'erne. De var begejstrede for hans kirkelige tanker og nationale forestillinger, og deres emnevalg og målgruppe var i vid udstrækning sammenfaldende med hans, for de unge guldalderkunstnere ville male Danmarks natur og historie for hele folket. Lundbye skrev i sin dagbog i 1843 om sagaer, kæmpeviser og kæmpehøje: 
hvad gavn, når de er døde for folket, de skal atter komme til ære og værdighed (...) Nu ser jeg dem først i deres sande glans, der fører til nye gerninger i de gamles ånd (Eller 1983, 8).

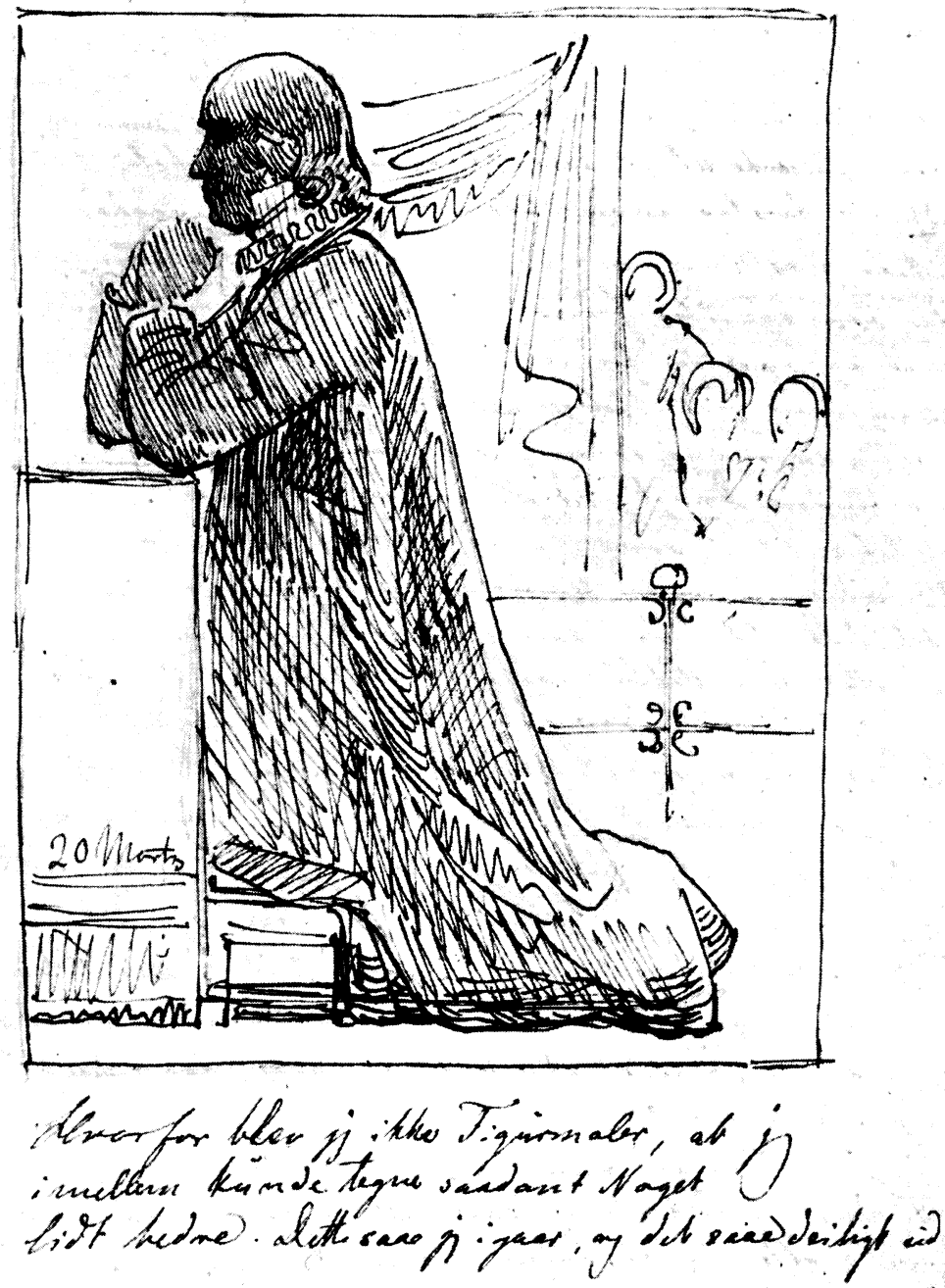

J. Th. Lundbye: Grundtvig. Teksten under tegningen afspejler Lundbyes betagelse af Grundtvig: "Hvorfor blev jeg ikke Figurmaler, at jeg imellem kunde tegne saadant Noget lidt bedre. Dette saae jeg i igaar, og det saae deiligt ud." Pennetegning i Lundbyes dagbog for 1843. (Foto: Det Kongelige Bibliotek.) 
Forbindelsen mellem Grundtvig og Lundbye fremgår for eksempel af en billedrulle med en rejseskildring, som Lundbye tegnede til billedehuggeren Freunds børn. Det sidste billede heri er tegnet til et vers af Grundtvig: "Men Dansken har hjemme, hvor Bøgene gro paa Strand hos den fagre Kiærminde, og deiligst vi finde ved Vugge og Grav den blommede Eng i det bølgende Hav". ${ }^{14}$ I vid udstrækning var det romantikken og Grundtvigs billedrige digtning, der satte et afgørende præg på Lundbyes landskabskunst (William Gelius 1994, 181). ${ }^{15}$

Samspillet mellem guldaldermalerne og Grundtvig blev præsenteret i jubilæumsudstillingen "Grundtvig og Danmark" på Det Nationalhistoriske Museum på Frederiksborg i 1983. Den indledtes med en skildring af Grundtvigs Danmark $i$ form af samtidige landskabsbilleder ledsaget af vers, der indirekte skildrede motiverne. Til trods for, at Grundtvig ikke værdsatte billedkunst, har han alligevel udøvet en markant påvirkning på en række af datidens bedste kunstnere - og gennem deres værker ser vi fortsat på naturen med Grundtvigs blik og opfatter den som et udtryk for "det ægte danske", som Lundbye skrev i sin dagbog i 1842 (Eller 1983, 8).

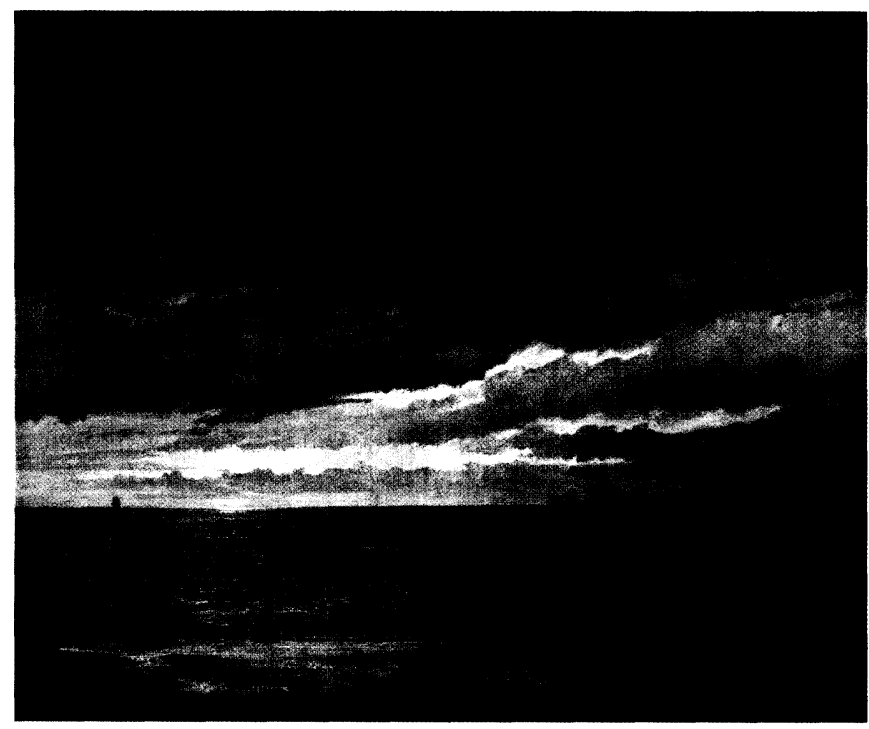

J. Th. Lundbye: Den opadgaaende Sol over Havet. 1838. Solen, der er decentralt placeret $i$ billedets venstre halvdel, er det livgivende element, og titlen afspejler, at solens frembrud er det egentlige motiv. Maleriet fremstår som en fuldstæendig illustration til "Den signede Dag med Fryd vi seer, / Af Havet til os opkomme". Skibet, der også er til venstre, knytter båndet over havet til himlen og bliver herved et sendebud til "Landet bag Hav, / Hvor Evigheds Soel skinner klart allenstund / Paa Saligheds Grund", som Grundtvig skildrer det i festsalmen "O Christelighed!" 1853. (Foto: Ribe Kunstmuseum.) 
Det er ganske vist kun indirekte, at vi ser på landskabet med Grundtvigs øjne, men indtrykket forstærkes i en række af Grundtvigs sange, som lader Det hellige Land fremstå mere dansk end bibelsk. Det er for eksempel tilfældet i sangen om Jesu barndom: "I Nasaret der var saa smukt / Paa Brinkerne de steile, / Der saae man over Skoven lukt / Vel Snese Skibe seile." Og et andet eksempel: "Nat i Østen er ei saa lang / Som her ved Juletider, / Ei det fyger, som her, i Vang, / Og ei paa Iis man skrider. / Dog trækker kiøligt tilmarks det der / Som i det tidlige Foraar her”. Retorikprofessoren Jørgen Fafner har peget på denne hyppige jævnføring og dens følgevirkning:

De to udvalgte lande, Det hellige Land og Danmark, er, som ofte hos Grundtvig, set i ét blik. Når danskeren i dag kommer til Israel, oplever han landet på samme naivt-naturlige måde som barndommens bibelhistorie (Fafner 2000, 265 og 269).

\section{Grundtvig og den nationale symbolik}

Stort set alle danske nationale symboler - hvad enten de er officielle eller uofficielle - kan man genfinde i Grundtvigs forfatterskab. Det er imidlertid svært at klarlægge, på hvilken måde og i hvor høj grad Grundtvig har været inspiratoren for udbredelsen af dette eller hint symbol. Det kræver, at man undersøger spredningsveje og ikke mindst virkningshistorie. De vigtigste spredningsveje har utvivlsomt været Salmebogen og Højskolesangbogen, for sangdigtet vejer tungest $\mathrm{i}$ Grundtvigs samlede produktion. Han havde en stærk tro på sangens folkeopdragende betydning og formåede at levendegøre dens indhold og budskab gennem en mundtlig form. Det kommer klart frem i hans talrige digte i Salmebogen og Højskolesangbogen. Begge samleværker er udkommet $\mathrm{i}$ fornyede udgaver, rettet mod samtidens brugere, og derved har de været med til at fastholde Grundtvigs betydning i dag.

Grundtvigs salmer er ofte blevet opfattet som udtryk for noget meget dansk. Derfor blev han også stort set fravalgt i den første salmebog, der blev lavet til de dansksprogede menigheder i Sønderjylland efter indlemmelsen i Preussen. Den danske kongerigske salmebog blev opfattet som en alt for dansk manifestation, og den måtte ikke bruges af de dansksprogede menigheder af frygt for, at de skulle fortsætte med at opfatte sig som en dansk kirkeprovins. I stedet for blev det besluttet at udgive en salmebog på dansk rettet mod det danske mindretal i provinsen Slesvig-Holsten. Det blev en stærkt revideret udgave af Den Pontoppidanske Psalmebog, og den udkom i 1876. Salmebogen var tilrettelagt af den tysksindede domprovst i Haderslev, C. A. Valentiner, og han havde kun medtaget 5 salmer og gendigtninger af Grundtvig. I tråd hermed var der ved Brorsons oversættelser og gendigtninger kun anført de tyske forfatteres navne. Valentiners sangbog var med til at øge de nationale modsætninger på 
det kirkelige område, da man fra dansk side mente, at denne salmebog ville fremme fortyskningen, og i en række sogne valgte man fortsat at bruge ældre danske salmebøger, blandt disse især Roskilde Konvents Salmebog. I 1889 blev denne salmebog afløst af en ny, der var lavet af overvejende dansksindede præster i Sønderjylland, men med den slesvig-holstenske generalsuperintendent (biskop) Theodor Kaftan som formand i salmebogsudvalget. I en indberetning til Konsistoriet $\mathrm{i}$ Kiel om salmebogsbrugen i Nordslesvig havde han bemærket: "Roskildesalmebogen er yndet i grundtvigske kredse og ikke uden politisk betænkelige salmer af dansk national farve" (Kjærgaard 2003, 300).

Desværre nævnes ikke de pågældende salmer, og Kaftan var langtfra afvisende over for Grundtvigs salmedigtning. Den nye salmebog for dansksprogede menigheder, den såkaldte "Nordslesvigske Salmebog", kom således til at indeholde 624 numre, og heraf var der 90 salmer og gendigtninger af Grundtvig. Men til undervisningsbrug var Valentiners salmebog enerådende, så de sønderjyske børn mødte kun Grundtvigs salmer i kirken og hjemmet, ikke i skolen.

Efter 1920 ændredes dette forhold sig afgørende, og allerede i genforeningsåret fik en af Grundtvigs salmer en særlig status. Det var "Den signede Dag", der blev sunget overalt, først ved afstemningsmøderne i januar og februar, dernæst ved genforeningsfester gennem foråret og sommeren. $\mathrm{Og}$ da skolerne genåbnede efter sommerferien under dansk ledelse, var det denne salme, der overalt blev sunget ved den første morgensang. Mange ældre sønderjyder har fortalt, at de som børn ikke var i tvivl om, hvad der blev sigtet til med slutstrofen "Saa reise vi til vort Fædre-Land". Det var jo Danmark! Og salmen sluttede jo med hjertelig hyldest til det danske folk: "Saa frydelig der til evig Tid / Med Venner i Lys vi tale!". I mange grundtvigske hjem i Sønderjylland blev salmen sunget ved alle familiefester, og her udvikledes den tradition, at man rejste sig op under det sidste vers - i respekt for hjemkomsten til fædreland og nation. Denne sammensmeltning af den nationale og den kristne identitet er en meget markant del af den grundtvigske arv.

Den mest virkningsfulde udbredelse af Grundtvigs idéverden og forestillinger om danskhed er sket og sker fortsat gennem Højskolesangbogen, der udkom første gang i 1894. Den seneste udgave er den 17. fra $1989 .{ }^{16}$ Heri er der 119 sange af Grundtvig, hvilket er $21 \%$ af de i alt 572 sange i sangbogen. Dette viser bedre end mange ord, hvor meget Grundtvigs billedverden forsat fylder i vore opfattelser af danskheden. I forhold til den 16. udgave fra 1972 er mange af de fremmedsprogede sange atter forsvundet, og et par nye temaer indført: "Sprog og ånd" samt "Folkelivet". Disse to temaer afspejler Grundtvigs idéverden, og i tråd hermed er Niels Skovgaards 
titelvignet nu for første gang gengivet to gange, både før titelbladet og på bogens ryg. Også dette viser med al tydelighed, hvad der er tyngdepunktet i indholdet. ${ }^{17}$ Helt $\mathrm{i}$ tråd med dette indledes og afsluttes Højskolesangbogen med Grundtvig-tekster, der ligger ud over den almindelige nummerrække. ${ }^{18}$

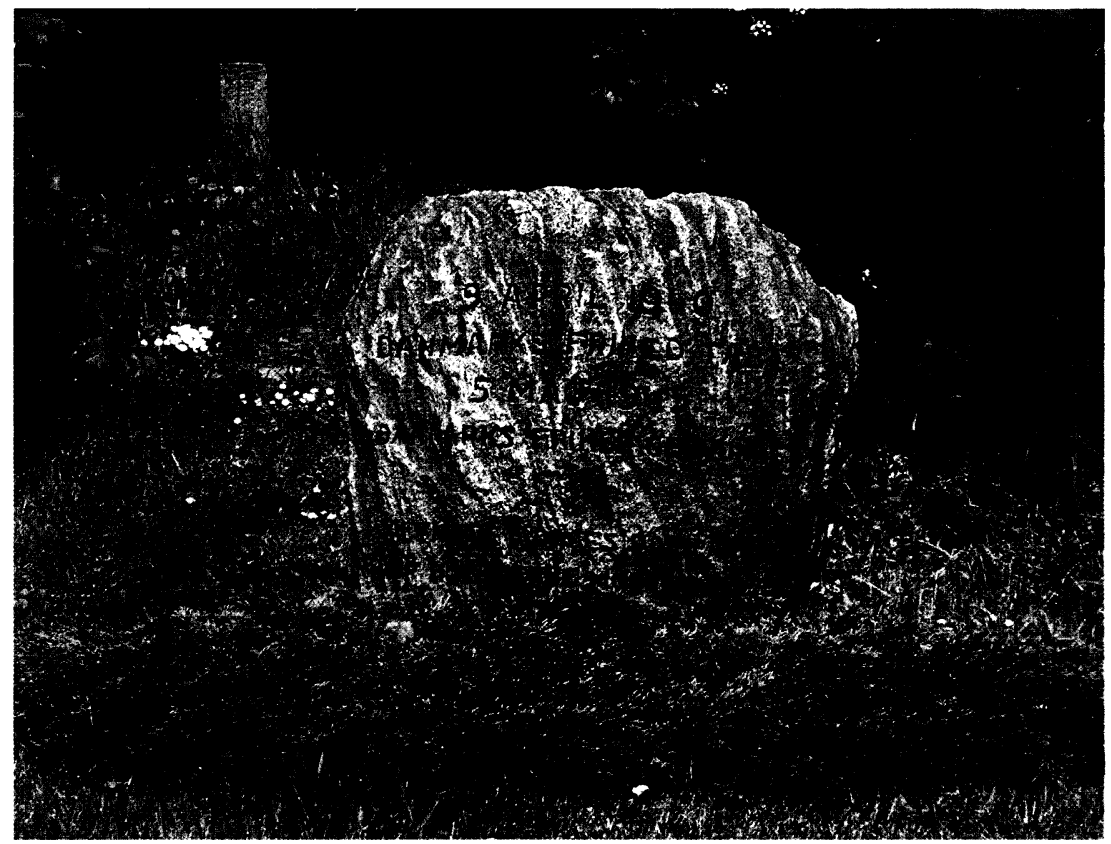

Befrielsesmindesten i Soro med citat af Grundtvig. Over hele landet blev der i 1945 rejst omkring 370 mindesten for Danmarks befrielse, og på en række af dem blev der indhugget citater af Grundtvig. Et af de hyppigste, som også bruges på mange mindesten for genforeningen, er dette 'forbedrede' citat fra "Den signede Dag": "Altid det dages dog paa ny / naar Hjerterne Morgen vente". Endringen skyldes, at ordet 'immer' fejlagtigt blev opfattet som tysk sprogbrug og derfor udskiftet med 'altid'. At der herved sker en poetisk forringelse, har tilsyneladende ikke anfægtet initiativtagerne. Befrielsesmindestenen er anbragt på en gravhøj ved Pedersborg kirke ved Sorø, og således knyttes det dansknationale i grundtvigsk tolkning nært sammen med det oldnordiske og kristne. (Foto: Merete Carlsen.)

Denne 17. udgave er blevet trykt $\mathrm{i}$ over $1 / 2$ million eksemplarer, og dermed er det den danske sangbog gennem tiden, der er udkommet $\mathrm{i}$ størst oplag. ${ }^{19}$ Salgstal i sig selv fortæller naturligvis ikke om betydning, men de giver fingerpeg. Det er også af betydning, at Højskolesangbogen er med til at sætte normer for og at give inspiration til andre sangbøger, især skolesangbøgerne. Danmarks originaleste bidrag til folkeopdragelsens historie er Grundtvigs helhedssyn på salme, historisk vise, fædrelands- og folkelivssang, 
hævder Jørgen Fafner i sin bog Dansk Vershistorie, og han fortsætter:

Hovedgenrernes stadige strejftog ind på hinandens gebeter afgiver et billede på den usædvanlige rigdom, der råder i dansk sang- og vershistorie. Vi har salmer, der går langt udenfor de grænser, som en strengere observans sætter for salmer, vi har fædrelandssange, der ikke blot er anprisninger af fædrelandet, men sange til modersmålet og sange om folkets historie, livsvilkår og opdragelse til mennesker. Det er i alt væsentligt Grundtvigs værk (Fafner 2000, 317).

\section{Forkortelser}

Danskeren I-IV: N. F. S. Grundtvig, (1848-51), Danskeren. Et Ugeblad, bind 1-4, København.

DV I-IV: N. F. S. Grundtvig, (1816-19), Danne-Virke, et Tids-Skrift, bind 1-4, København.

US I-X: Holger Begtrup (udg.) (1904-09), Nik. Fred. Sev. Grundtvigs Udvalgte Skrifter, bind 1-10, København.

\section{Litteraturlister}

\section{Vorker af Grundtvig}

Grundtvig, N. F. S. (1816-19), Danne-Virke, et Tids-Skrift, bind 1-4, København.

Grundtvig, N. F. S. (1848-51), Danskeren. Et Ugeblad, bind 1-4, København.

Begtrup, Holger (udg.) (1904-09), Nik. Fred. Sev. Grundtvigs Udvalgte Skrifter, bind 1-10, København.

Vorker af andre forfattere

Adriansen, Inge (1987), "Mor Danmark. Valkyrie, skjoldmø og fædrelandssymbol" i Folk og Kultur. Arbog for Dansk Etnologi og Folkemindevidenskab, Viborg, 105-163.

- (1999), "Danske kompagnifaner som preussisk trofæ og tysk forsoningsgave" i Sønderjyske Museer, Aabenraa, 43-48.

- (2003), Nationale symboler $i$ Det danske Rige, bind 1-2, København.

Adriansen, Inge \& Jenvold, Birgit (1995), "Den tapre landsoldat menigmands heltemonument" i Axel Johnsen (red.), Med Gud for Konge og Fødeland! Für Freiheit und Einheit!, Sønderborg, 5569.

Auken, Sune (2005), Sagas spejl. Mytologi, historie og kristendom hos N. F. S. Grundtvig, København.

Bak, Karl (1977), Højskolesangbogens historie, København. 
Borum, Poul (1983), Digteren Grundtvig, København.

Eller, Povl (udg.) (1983), Grundtvig og Danmark. Katalog fra Det Nationalhistoriske Museum på Frederiksborg, Hillerød.

Fafner, Jørgen (2000), Dansk Vershistorie, bd. 2, København.

Gelius, William (1994), "Johan Thomas Lundbye i romantisk perspektiv" i Henschen et al. 1994, 169-181.

Henschen, Eva; Melander, Torben \& Miss, Stig (red..) (1994), Johan Thomas Lundbye 1818-1848 (...) at male det kjore Danmark, København.

Holm, Anders (2001), Historie og efterklang. En studie i N. F. S. Grundtvigs tidsskrift Danne-Virke, Odense.

Johansen, Steen \& Høirup, Henning (udg.) (1983), Grundtvigs Erindringer og Erindringer om Grundtvig, København.

Kjærgaard, Jørgen (2003), Salmehåndbog, bd. 1, Salmehistorie, København.

Kuhn, Hans (1990), Defining a Nation in Song. Danish patriotic songs in the songbooks of the period 1832-1870, København.

Lundgreen-Nielsen, Flemming (1982), "N. F. S. Grundtvigs 'Langt høiere Bjerge"” i Henrik Glahn et al. (red.), Hvad Fatter gjør (...): boghistoriske, littercere og musikalske essays tilegnet Erik Dal, Herning, 289-307.

_ (1992), "Grundtvig og danskhed" i Ole Feldbæk (red.), Dansk Identitetshistorie, 3, Folkets Danmark 1848-1940, København, 9187.

(1994), "Grundtvigs nordisk-mytologiske billedsprog - et mislykket eksperiment?" i Grundtvig-Studier 1994, København, 142-198.

Lönnroth, Lars (1979), "Frihed for Loke såvel som for Thor”. Den nordiske mytologin som politiskt redskap i grundtvigiansk bondeog folkhögskolemiljö, Serie om folkekultur, nr. 1, Aalborg.

Manniche, Jens Chr. (1992), "Historieskrivningen 1830-1880" i Nanna

Damsholt et al. (red), Historiens historie, Danmarks Historie, bd. 10, København, 199-265.

Rørdam, Peter (1864), Psalmer for danske Krigere, København.

Thodberg, Chr. \& Thyssen, Anders Pontoppidan (red.) (1983),

Grundtvig og grundtvigianismen $i$ nyt lys: Hovedtanker og Udviklingslinier fra de senere Ars Grundtvigforskning, Århus.

Toldberg, Helge (1950), Grundtvigs symbolverden, København.

\section{Noter}

Denne artikel er baseret på et foredrag holdt ved Center for Grundtvigstudier, Aarhus Universitet i marts 2006 om temaet Grundtvig og den tidlige tradition.

Det bør understreges, at den ikke er et bidrag til nogen symbolanalyse hos Crundtvig - det er en sag for teologer og litterater - her forsøges kun en 
udredning af samtidens og eftertidens brug af udvalgte dele af Grundtvigs symbolverden.

Præsentationen af den nationale symbolik bygger på Adriansen 2003.

2 Et af de første digte om Dannebrog er "Kors-Banneret", trykt i Theologisk Maanedsskrift i 1825. Digtet handler om Grundtvigs kamp for den rette kristendom, og Dannebrog skildres især som korsfarerflag.

3 Teksten blev første trykt af Lundgreen-Nielsen i 1992.

4 Danske Heltesagn er kommet i 14 udgaver, og det seneste oplag er fra 2001.

5 Holm 2001 gennemgår en række hovedtekster i Danne-Virke og analyserer dem ud fra begrebet efterklangsbevidstheden, som er en betydningsbærende manifestation i nutiden af noget fortidigt

6 Dannevirke udkom som ugeblad 1838-1851, derpå som dagblad.

7 Den første udgave af Danebod-visen er på 14 strofer, skrevet af den sjællandske præst Laurids Olufsen Kok og trykt i Peder Syv: Kampevisebog. København 1695. Grundtvig bearbejdede denne sang flere gange i $1816,1840,1847$ og 1848. Han skrev også selvstændige digte med samme begyndelse og versemål..

8 De her citerede strofer er fra 1848-versionen i Nutzhorn og Schrøder 1872. Sangen omfatter originalens strofe 1-6 og 14 og har været gengivet i samtlige udgaver af Folkehøjskolens Sangbog.

9 Traditionen fremgår af Poul Dams note under sangen i Folkehøjskolens Sangbog, 17. udgave. Dam har i Grundtvig-Studier 1999 redegjort for injuriedommen og den dermed følgende censur.

10 Tak til Flemming Lundgreen-Nielsen, som har påpeget, at der ikke er belæg for traditionen, og at den derfor ikke medtages i den kommende tyske oversættelse af Grundtvigs værker.

11 Begtrup anfører i Udvalgte Skrifter (US VIII, 179), at Grundtvig skrev sangen mellem jul og nytår 1837 efter at have modtaget et brev dateret 28. december om, at censuren var ophæves. Senere skribenter, bl.a. Hans Brix, udbygger historien, så det bliver julenat, at Grundtvig digter sangen om modersmålet. Som påpeget af Hans Kuhn var dette dog umuligt af hensyn til kronologien. (Kuhn 1990, 133).

12 Op.cit. nr. 116.

13 Det bør nævnes, at Flemming Lundgreen-Nielsen mener, at Danmarks ånd lige så vel kan tolkes som den aldrende kong Vermund, og at denne tolkning vil gøre foryngelsen i sidste strofe mere underfuld (LundgreenNielsen 1992, 125-129).

14 Det er en del af anden strofe i "Langt høiere Bjerge".

15 Gelius tilføjer, at efterhånden som religiøs tvivl og læsningen af Søren Kierkegaard fik et fastere tag i Lundbyes sind, var det, som om hans "åndelige øje” blev lukket, og hans landskabsmaleri tabte højde.

16 Den 18. udgave af Højskolesangbogen er undervejs og vil udkomme i efteråret i 2006.

17 Skovgaards tegning er ganske vist ledsaget af et Ingemann-citat "Det var de danske Skjalde, der sang" fra digtet "Holger Danskes Vugge" i Holger Danske. En digtkreds i 5 Sange, København 1834. Dette fortæller om Ingemanns stærke placering i den grundtvigske højskoleverden, men illustration og tekst er lige så dækkende for Grundtvigs idéverden som for 
Ingemanns.

18 Forrest er et vers fra "For bønder himlens fugle mer" og allerbagest er det digtet "Danmarks engel" fra 1850.

19 Oplaget for 1.-15. udgave er anført i Bak 1977, 106. Oplagstallet for 16. og 17. udgave er venligst oplyst af Nina Bjerregaard, Folkehøjskolernes Forening i Danmark, i brev af 17. oktober 2001. MSS, Nat. symboler 3.1.2.12. 